The Journal of Agriculture and Environment Vol:17, Jun.2016

\title{
PERCEPTION ANALYSIS OF CLIMATE CHANGE AND ADAPTATIONS BY SMALLHOLDER FARMERS IN NEPAL
}

\author{
N.P. Ghimire ${ }^{1}$, M. Aryal ${ }^{2}$, P.P. Regmi ${ }^{3}$, R.B. Thapa ${ }^{4}$, K.R. Pande ${ }^{5}$ and K.P. Pant ${ }^{6}$
}

\begin{abstract}
Climate change is posturing warning on present and future food security in low income countries. But, the actual effect of the climate change is still unknown. This study examined the farmer's perception on climate change and strategies employed to adapt using primary and secondary data collected through household survey and reported by government. Statistical analysis is used for exploring the adaptations by farmers for the negative impact of_climate change on domestic production of major cereals crops. The results are discussed at district level empirically and major variables are found statistically significant. This study conclude that there is a need for adaptations strategy by government authority in environmental management and agricultural sustainability in Nepal to come to terms with negative impacts of climate change and likely positive and beneficial response strategies to global warming. The paper suggests some policy measures for improving adaptations and food security situation in the country and open up some areas for further research.
\end{abstract}

Key words: Adaptations, cereal crops, climate change, crop yield, perceptions

\section{INTRODUCTION}

The relationship between climate change and agriculture is two-way; agriculture contributes to it in several ways and climate change in general adversely affects agriculture. Agricultural production and productivity are primarily dependent on climatic factors, and the favorable climatic conditions are crucial in generating optimal yield. So, economy of the country is more sensitive to agriculture and climate change (Alam and Regmi, 2004). Though Least Developed Countries (LDCs) did not contribute much in increasing the level of GHGs they are highly affected by climate change and have low adapting capacity (Orindi and Eriksen, 2005 and Glieck, 1989). Climate Change has serious impact on cereal crops and livelihood of farming community through increasing uncertainties in agricultural production due to the disturbances in the natural system such as climate change, environmental degradation and rising competition for land and water.

The agricultural sector with low productivity growth is facing high rate of population growth coupled with the effects of climate change leading to serious consequences for sustainability. Intensive rain concentrated in a particular month has a devastating effect on crop production (McCarl, et al., 2001). The majority of the farmers in Nepal hills depend on the monsoon rain for crop cultivation. In the recent years, intensity, amount and distribution of rainfall are changing in unpredictable manner. So, the changes in the rainfall pattern may be fatal for them. Once the climate is disturbed, the whole agriculture system is affected. Climate change affects food, feed, fiber and fuel (4"F") causing food insecurity. Out of 26 million populations, more than 2 million faced food insecurity in Nepal (IAASTD, 2008). If the increase in temperature exceeds by 1.5 to $2.5^{\circ} \mathrm{C}$, there will be the risk of extinction of plant and animal species by $20-30 \%$ (IPCC, 2007).

Climate change affects green sectors more than other sectors of the economy. Agricultural production is the outcome of the freshwater irrigation supplies from rivers and spring and rainfall, fertile soil terraced and maintained by the farmers for generations. Agriculture production depends on nature and gets affected by the change in the climatic parameters such as expected changes in frequency, duration, intensity and geographic distribution of rainfall and snowfall and increased frequency, duration and intensity of droughts (FAO/NRCB, 2008). Effects of climate change on agriculture are particularly high as the agriculture produces food and provides the primary source of livelihood for large chunks of weaker sections of the society (Pant, 2012).. If agricultural production in Nepal is adversely affected by the climate change, the livelihoods of two-thirds of the labor force, particularly of the rural poor will be at threat.

\footnotetext{
1Joint Secretary, National Spices Crop Development Program, Khumaltar

${ }^{2}$ Market Research and Statistics Management Program, Hariharbhawan

${ }^{3}$ Professor, Department of Agriculture Economics, IAAS, TU

${ }^{4}$ Professor, Department of Entomology, IAAS, TU

${ }^{5}$ Professor, Department of Soil Science, AFU, Chitwan

${ }^{6}$ Agriculture expert, FAO
} 
Due to unscientific cropping systems, inappropriate infrastructure and poor technology, Nepalese agriculture is equally sensitive to the long dry spell and high temperature during spring season. As Nepal is an agricultural country practicing mostly conventional system of farming with inadequate infrastructures, the effects of global climate change are expected to be very serious (Maharjan et al., 2011). In fact, a series of regular and extreme weather events in Nepal have caused a significant decline in the country's crop yield.

Under such circumstances, most of the works have been done on changes in temperature and rainfall as proxy indicators for climate change and tried to show that alteration to these variables affect the 'mean' annual crop yield. To approach the issue appropriately, accounting local communities is essential, since they perceive climate as having a strong spiritual, emotional, and physical dimension. Community response is critical to understand \& estimate effects of climate change on production \& food supply for adaptation. Thus, it is vital to seek adaptation strategies to cope its effects on crop yield. The effect of climate change on crop yield and adaptation strategies are the predominant interest in recent time.

The study analyzes the perception about climate change and its impact on agriculture in Nepal particularly small holders and farmers adaptations based on household survey data. The scope of the paper is limited to the analysis of perception and adaptations against climate change by the farmers.

Recent research has focused on regional and national assessments of the potential effects of climate change on agriculture (Lobell, et al, 2008; Hassan and Nhemachem, 2008; Fischer et al, 2002). These efforts have, for the most part, treated each region or nation in isolation and do not integrate (i.e. combined biophysical and economic) assessment of the potential effects of climate change on proletariat agriculture focusing mostly on world agriculture (ODI, 2007; Segerson and Dixon, 1998). Therefore, this research also intends to investigate the effects of climate change on small holders at community level and their perception and adaptation to changing in climate. This will helps to synthesize a better understanding of the communities' perception of climate change and existing adaptation strategies in Nepal.

\section{METHODOLOGY}

\section{AREA OF STUDY}

Area of study is Rupandehi district of western development region and is known for its arable food crop production. Purposive sampling was used to select district and two Village Development Committees namely Manmateria and Hatti Bangai based on primary information. Random sampling was used to select sample households within the e communities and the communities that are prone to climate change impact.

\section{MATERIALS AND METHODS}

The study administered questionnaire and held Focus Group Discussions to elicit information, where 70 valid responses from household survey were used for further analysis. Both structured questionnaire and interviews were held with indigent and local government officials and all other stakeholders on climate change knowledge and adaptation. The study uses logit regression analysis to examine the characteristics that best explain variation in the measures of attitudes of the indigent perception and adaptation level to climate change and factors that influences such decisions. The study decomposes various measures of climate change adaptation. In addition, the study also uses Focus Group Discussions (FGDs) to find out the level of understanding of climate change at community level and their perception and level of preparedness. Panel data were collected during the late rain of September-October and early rain of March-April, 2014 to understand the variation of climatic conditions and its effect on agricultural outputs and other form of activities of food crop farmers. 


\section{ANALYTICAL APPROACHES}

Logit model was adopted and used to analyze the determinants of the perception and adaptation level of climate change. The choice of the explanatory variables in the model was based on literature review (Ghazouani and Goaied 2001; Rodriquez and Smiths, 1994; Mendels et al., 1994). The estimating logarithmic equation is

$l i=\beta_{0}+\beta_{1} \ln _{1} X_{1}+\beta_{2} \ln _{2} X_{2}+, \ldots,+\beta_{19} \ln _{19} X_{19}$

The dependent variable $\mathrm{l} i$ is a dichotomous variable, which is one when a respondent perceive any of the climate change variations and adapt to the changes and zero otherwise.

The explanatory variables used in the Logit Models and hypothesized as determinants of respondents poor in the level of perception and adaptation to climate change (that is specialized in only mono cropping) are:, 1 for mono and 0 otherwise. Increased temperature $\left(X_{1}\right)$, decreased temperature $\left(X_{2}\right)$, altered climate range $\left(X_{3}\right)$, changed timing of rains $\left(X_{4}\right)$, frequency of droughts $\left(X_{5}\right)$, noticed climate change $\left(X_{6}\right)$, cereal/legume intercropping $\left(X_{7}\right)$, mulching $\left(X_{8}\right)$, practiced zero tillage $\left(X_{9}\right)$, making ridges across farms $\left(X_{10}\right)$, farm size $\left(X_{11}\right)$, own heavy machines $\left(X_{12}\right)$, household size $\left(X_{13}\right)$, farming experience $\left(X_{14}\right)$, education $\left(X_{15}\right)$, age of farmers $\left(X_{16}\right)$ access to extension facilities (ACEXT) $\left(X_{17}\right)$ Dummy, if access 1 , otherwise 0 , access to credit facilities (ACCRE) $\left(X_{18}\right)$ and $\operatorname{Sex}\left(X_{19}\right)$

\section{RESULTS AND DISCUSSIONS}

Figure 1 and 2 present farmers' perception about temperature change and precipitation in Rupandehi district in 2014. Majority of the respondents (46\%) expressed that they perceived the increased temperature in 2014. Majority of the respondents (30\%) perceived the decreased rainfall and $33 \%$ perceived the change in timing of rains in Rupandehi district (Figure 2).

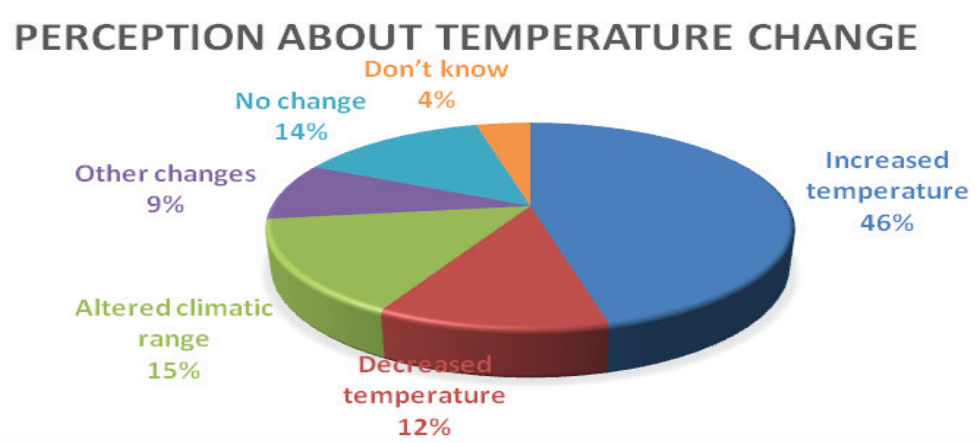

Figure 1 : Farmers’ perception about temperature change in Rupandehi district, 2014

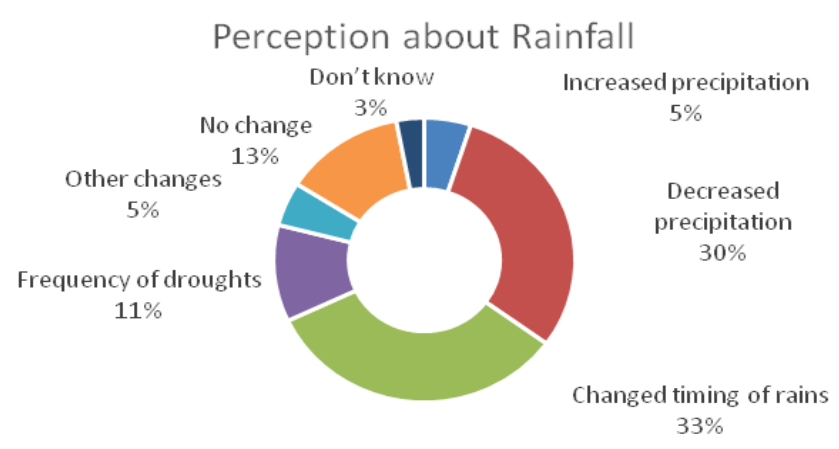


Figure 2 : Farmers' perception about precipitation in Rupandehi district, 2014

Table 1 presents farmers' actual adaptation measures and practices actually followed, thus, grouped into different categories (Table 2). These strategies, however, are mostly followed in combination with other strategies and grouped into the following adaptation options: diversifying into multiple and mixed crop-livestock systems, and switching from crops to livestock and from upland to irrigation, practicing zero tillage, making ridges across farms and cereal/legume intercropping.

Table 2 reveals that multiple cropping mixed with livestock rearing under upland conditions is the dominant system (27.75\%). Cereal/legume intercropping is the second most common strategy (21.28\%), and multiple cropping without livestock under dry land $(13.1 \%)$ comes third.

Diversification from farming to non-farm the most common adaptation practice (23\%) (Table 2). The implication is farmers are gradually moving away from farming to non-farm activities. The main adaptation strategic measures was followed as per Food and Agriculture Organization (FAO) classification (Dixon et al., 2001) and were used to classify the strategic measures into thirteen.

Table 1 : Farmers' perceived adaptations

\begin{tabular}{llc}
\hline SN & Variable & \% of Respondents \\
\hline 1 & Planting different crops & 3 \\
2 & Planting different varieties & 5 \\
3 & Practicing crop diversification & 4 \\
4 & Different planting dates & 7 \\
5 & Shorten length of growing period & 6 \\
6 & Move to different site & 2 \\
7 & Change amount of land & 1 \\
8 & Changes from crops to livestock & 2 \\
9 & Changes from livestock to crops & 1 \\
10 & Adjust livestock management practices & 1 \\
11 & Farming to non-farming & 23 \\
12 & Non-farming to farming & 2 \\
13 & Increase irrigation & 3 \\
14 & Change use of chemicals, fertilizers and pesticides & 5 \\
15 & Increase water conservation & 8 \\
16 & Soil conservation & 5 \\
17 & Shading and shelter & 8 \\
18 & Use insurance & 2 \\
19 & Prayer & 3 \\
20 & Other adaptations & 2 \\
21 & No adaptation & 7 \\
\hline
\end{tabular}

Table 2 : Actual adaptation measures used by farmers

\begin{tabular}{clc}
\hline SN & Adaptation measures & \% of Respondents \\
\hline 1 & Specialized crop under upland & 2.21 \\
2 & Specialized crop under irrigation & 1.03 \\
3 & Specialized livestock under upland & 1.02 \\
4 & Specialized livestock under irrigation & 0 \\
5 & Multiple crops under upland & 13.1 \\
6 & Multiple crops under irrigation & 0.27 \\
7 & Mixed mono-crop/livestock under upland & 4.95 \\
8 & Mixed mono-crop/livestock under irrigation & 2.04 \\
9 & Mixed multiple crops/livestock under upland & 27.75 \\
10 & Mixed multiple crops/livestock under irrigation & 4.24
\end{tabular}


The Journal of Agriculture and Environment Vol:17, Jun.2016

11 Practiced zero Tillage

9.73

12 Making ridges across farms

12.38

13 Cereal/legume intercropping

21.28

Table 3 : Results of the Logit Regression Model

\begin{tabular}{clcc}
\hline SN & Variables & Coefficient & t-Values \\
\hline 1 & Increased Temperature $\left(X_{1}\right)$ & $0.090 \mathrm{E}-02$ & $4.24^{* * *}$ \\
2 & Fall in Temperature $\left(\mathrm{X}_{2}\right)$ & $-0.298 \mathrm{E}-01$ & $-2.923^{* *}$ \\
3 & Altered Climate Range $\left(\mathrm{X}_{3}\right)$ & 0.3911 & 1.321 \\
4 & Changed timing of rains $\left(\mathrm{X}_{4}\right)$ & $-0.161 \mathrm{E}-01$ & $-3.3561^{* * *}$ \\
5 & Frequency of Droughts $\left(\mathrm{X}_{5}\right)$ & -0.8751 & -0.2783 \\
6 & Noticed Climate Change $\left(\mathrm{X}_{6}\right)$ & 0.6172 & 1.6061 \\
7 & Cereal/legume Intercropping $\left(\mathrm{X}_{7}\right)$ & 0.5883 & $2.5412^{* *}$ \\
8 & Mulching $\left(\mathrm{X}_{8}\right)$ & $0.22 \mathrm{E}-05$ & $2.1271^{*}$ \\
9 & Zero Tillage $\left(\mathrm{X}_{9}\right)$ & $913 \mathrm{E}-06$ & $3.112^{* * *}$ \\
10 & Making Ridges across Farms $\left(\mathrm{X}_{10}\right)$ & 0.719 & $2.752^{* *}$ \\
11 & Farm size $\left(\mathrm{X}_{11}\right)$ & $0.797 \mathrm{E}-07$ & $2.1242^{*}$ \\
12 & Owned heavy machines $\left(\mathrm{X}_{12}\right)$ & $-0.893 \mathrm{E}-01$ & $-4.4272^{* * *}$ \\
13 & Household size $\left(\mathrm{X}_{13}\right)$ & $-0.133 \mathrm{E}+11$ & $-4.4252^{* * *}$ \\
14 & Farming experience $\left(\mathrm{X}_{14}\right)$ & $0.5197 \mathrm{E}-04$ & $2.5731^{*}$ \\
15 & Educational status $\left(\mathrm{X}_{15}\right)$ & 0.1152 & $4.12^{* * *}$ \\
16 & Age $\left(\mathrm{X}_{16}\right)$ & 0.2117 & 0.2847 \\
17 & Access to extension facilities $\left(\mathrm{X}_{17}\right)$ & 0.368 & $2.73^{* *}$ \\
18 & Access to credit facilities $(\mathrm{ACCRE})\left(\mathrm{X}_{18}\right)$ & 0.2605 & $1.962^{*}$ \\
19 & Sex $\left(\mathrm{X}_{19}\right)$ & -0.4688 & -0.918 \\
\hline
\end{tabular}

***Sig. at $\mathrm{P}<.01,{ }^{* *}$ Sig. at $\mathrm{P}<.005,{ }^{*}$ Sig at $\mathrm{P}<.001$, Sig level $\mathrm{P}<.00001$ and constant 0.62 , Most of the explanatory variables are statistically significant at $10 \%$.

Table 3 presents the estimated marginal effects and t-levels from the logit model. The results show that most of the explanatory variables considered are statistically significant at $10 \%$. This study uses specialized (mono) cropping as the base category for no adaptation and evaluates the other choices as alternatives. The results show that altered climate change, noticed climate change frequency of droughts, age and sex had no significance effect on adaptation. While the increased temperature, intercropping of cereal/legume, mulching, zero tillage making ridges, farm size, farming experience, educational status access to extension and credit facilities are factors influencing adaptation positively (Table 3). However, fall in temperature, change timing of rains, own heavy machines and household size are also significant factors but influence adaptation negatively. This result suggests that the larger the occurrence of these variables, the poorer the adaptation.

The results revealed that fall in temperature influences the probability of switching away from mono-cropping more than changes in increased temperature. Similarly, the magnitudes of the marginal coefficients suggest that low outputs farming is a strong factor influencing the probability of switching to other systems that are better adapted to changes in temperature. Better accesses to extension and credit services seem to have a strong positive influence on adaptation. 
In addition, access to other farm assets such as heavy machinery is found to promote the use of large -scale farming. These results suggest that capital, land and labor serve as important factors for coping with adaptation. The choice of the suitable adaptation measure depends on factor endowments (i.e. family size, land area and capital resources). The more experienced farmers are, the more likely to adapt. Sex of the farmer did not seem to be significance in influencing adaptation, as the marginal effect coefficient was statistically insignificant and signs do not suggest any particular pattern. These results suggest that it is the experience rather than sex that matters for adapting to climate change.

\section{FOCUS GROUP DISCUSSIONS (FGDs)}

The events of higher temperature, faster water evaporation, increased incidence of pests and weeds, violent rainfall and hailstorms, delayed rainfall and less clearly defined seasons were responded by $89,72,716865$ and $65 \%$ of respondents on the issues of environment change for farming.

The costs associated with crops damaging weather events double each decade as the people (85\%) indicated that their crops were damaged by unpredicted rains and a series of freak hailstorm. Downpours (Rainfall) were more intense in the past years that always leave a trail of destruction on the farms $(76 \%)$. On the other hand, lack of water or delayed rainfall threatened crop production activities and $68 \%$ have switched their crop farming activities to other sectors due to low outputs. Many of the communities/farmers $(82 \%)$ do not attribute these changes to climate change but the soil productive.

There is need of agricultural insurance (54\%), weather alert (Radio and Television for daily weather forecast and relevance to agricultural activities) service $(71 \%)$ to help for effective adaptation. Weather forecasting services will further help them to facilitate in farming operations. The extension agents needs knowledge enhancement in some of the adaptation technologies as zero tillage, organic agriculture, and better land management techniques.

\section{CONCLUSION AND RECOMMENDATIONS}

Farmers in the area of study rely on rainfed agriculture with mono-cropping practicing upland condition. Due to low outputs from farms, as a result of low rainfall and increased temperature, farmers are diverting from mono-cropping to mixed cropping and mixed crop-livestock systems.. Educating the farmers were found to promote adaptation which implies that raising awareness of potential benefits of adaptation is an important policy measure through education and trainings.

Focus Group Discussions revealed lack of effective access to information on climate change. Thus, there is need for effective and reliable access to information on changing climate to dissuade farmers' attitude from spiritual angle. In addition, empowerment (credit or grant facilities) is crucial in enhancing farmers' awareness. This is vital for decision making and planning process for adaptation. Combining access to extension and credit ensures that farmers have the information for decision making and the means to take up relevant adaptation measures. Some of the recommendations are :

- Policies must aim at promoting farm-level adaptation through emphasis on the early warning systems and disaster risk management and also, effective participation of farmers in adopting better agricultural and land use practices.

- There is an urgent need for agro-meteorological information and services and alerts to be made accessible (when necessary) to farmers in an understandable forms.

- Massive field level on-the-spot campaign on the reality of climate change and its serious consequences on farming and food production is highly recommended so as to persuade against farmers' believe from spiritual angle.

- Need of readily availability emerging technologies and land management practices that could greatly reduce agriculture's negative impacts on the environment and enhancement of its positive impacts. 
The farmers and the communities are experiencing change in climate. Therefore policy of reliable and effective measures of adaptation need to be implemented and must be accessible to the end users. Looking at the issue of climate change adaptation, the role of agricultural extension is significant to raise both the consciousness of the need to climate change adaptation and possible methods of mitigating the impact to both the end users and policy makers. There is also need to design strategies that could help the farmers/rural communities adapt effectively against global warming. Early warming alerts and their interpretations in local language is required for preparedness against any damages in farming due to agro-metrological disasters.

\section{REFERENCES}

Alam, M. and Regmi, B. R., 2004. Adverse Impacts of Climate Change on Development of Nepal: Integrating Adaptation into Policies and Activities, Capacity Strengthening in the Least Developed Countries (LDCs) For Adaptation to Climate Change (CLACC), Working paper No.3, Bangladesh Centre for advanced Studies (BCAS), Dhaka, Bangladesh.

Dixon, J. Gulliver, A. \& Gibbon, D., 2001. Farming systems and poverty: Improving farmers' livelihoods in a changing world. FAO (Food and Agriculture Organization), Rome, and World Bank, Washington, DC.

FAO/NRCB. 2008. Poster presented at the International Conference on Food Security and Environmental Change, 24 April 2008. Oxford, UK.

Fischer, G. Shah, M. and van Velthuizen, H., 2002. Climate Change and Agricultural Vulnerability. International Institute for Applied Systems Analysis. Report prepared under UN Institutional Contract Agreement 1113 for World Summit on Sustainable Development. Laxenburg, Austria.

Ghazouani, S. and Goaied, M., 2001. The determinant of Urban and Rural Poverty in Tunisia' Laboratoired' Eonometrie Appliquee (LEA) faculte des Sciences Economiqueset de Tunis.

Gleick, P. H., 1989. Climate Change and International Politics: Problems Facing Developing Countries. Ambio 18(6), 333-339

Hassan, R. and Nhemachena, C., 2008. Determinants of African farmers' strategies for adapting to climate change: Multinomial choice analysis. African Journal of Resource Economics; Vol 2 No 1 March 2008, Pp 83-104

IAASTD, 2008. Executive Summary of the Synthesis Report of the International Assessment of Agricultural Knowledge Science and Technology for Development (IAASTD).

Intergovernmental Panel on Climate Change (IPCC), 2007. Climate Change 2007: Impacts, Adaptation, and Vulnerability. Contribution of Working Group II to the Third Assessment Report of the Intergovernmental Panel on Climate Change [Parry, Martin L., Canziani, Osvaldo

Lobell, D.B. Burke, M.B. Tebaldi, C. Mastrandrea, M.D. Falcon, W.P. and Naylor, R.L., 2008. Prioritizing climate change adaptation needs for food security in 2030. Science 319 (5863): 607-10

Maharjan, K. L., Joshi, N. P. and Piya, L., 2011. Effect of Climate Variables on Yield of Major Food-crops in Nepal: A Time-series Analysis. Journal of Contemporary India Studies: Space and Society, Hiroshima University, 1, pp. 19-26.

McCarl, B. A. Adams, R. M. \& Hurd, B. H., 2001.Global climate change and its impact on agriculture.Texas, USA: Texas A\&M University.

Mendelsohn, R. Nordhaus, W.D. and Shaw, D., 1994. The impact of global warming on agriculture: a Ricardian analysis. American Economic Rev 84(4):753-771

Orindi, V. A. \& Eriksen, S., 2005. Mainstreaming Adaptation to Climate Change in the Development Process in Uganda. Available online at: http://www.acts.or.ke/pubs/monographs/pubs/ecopolicy15.pdf

Overseas Development Institute (ODI), 2007. Climate change, agricultural policy and poverty reduction how much do we know? Overseas Development Institute (2007).

Pant, K. P., 2012. Climate Change and Food Security in Nepal. The Journal of Agriculture and Environment 13 (1): 9-17.

Rodriguez, A. and Smith, S., 1994. A comparison of Determinants of Urban, Rural and Farm poverty in CostaRica. World Development Vol. 22 pp 381-387

Segerson, K. and Dixon, B., 1998. Climate change and agriculture: the role of farmer adaptation. In: Mendelsohn R, Neumann J (eds) The economic impacts of climate change on the U.S. economy. Cambridge University Press, Cambridge. 